\title{
Release of transforming growth factor beta 1 and platelet derived growth factor type $A B$ from canine platelet gels obtained by the tube method and activated with calcium salts
}

\author{
Liberación de factor de crecimiento transformador beta 1 y factor de crecimiento derivado \\ de las plaquetas tipo $\mathrm{AB}$ a partir de geles de plaquetas caninos obtenidos mediante \\ el método del tubo y activados con sales de calcio
}

\author{
RF Silva $^{\text {ab }}$, GC Santana ${ }^{\mathrm{a}}$, FOP Leme ${ }^{\mathrm{a}}$, JU Carmona ${ }^{\mathrm{b}}$, CMF Rezende ${ }^{\mathrm{a}}$ \\ ${ }^{a}$ Escola de Veterinária, Universidade Federal de Minas Gerais, Belo Horizonte, Minas Gerais, Brasil. \\ ${ }^{\mathrm{b}}$ Grupo de Investigación Terapia Regenerativa, Departamento de Salud Animal, Universidad de Caldas, Manizales, Caldas, \\ Colombia.
}

\section{RESUMEN}

\begin{abstract}
Los objetivos de este estudio fueron: 1) medir las concentraciones del factor de crecimiento transformante beta 1 (TGF- $\beta_{1}$ ) y factor de crecimiento derivado de las plaquetas tipo AB (PDGF-AB) en plasma y gel de plaquetas (PG) activados con sales de calcio (gluconato o cloruro) en caninos, y 2) determinar las correlaciones entre los resultados celulares y la concentración de factores de crecimiento (GF). Se colectaron muestras de sangre de catorce perros Fila brasilero. Para obtener sangre entera y plasma se utilizó EDTA y para preparar los concentrados de plaquetas (PC) se utilizó solución ACD-A. Los PC fueron sometidos a gelificación por la adición de sales de calcio. Antes de la activación de los PC se realizó conteo de plaquetas y leucocitos. La concentración de los factores de crecimiento fue determinada mediante ELISA en los sobrenadantes de los PG y plasma. Se observó diferencias estadísticamente significativas $(\mathrm{P}<0,01)$ entre los valores de plaquetas y leucocitos en sangre entera y los $\mathrm{PC}$. No se encontraron diferencias estadísticamente significativas entre las concentraciones de TGF- $\beta_{1}$ y PDGF-AB en los PC y plasma en función de la sal de calcio empleada para la activación de los PC. La concentración de TGF- $\beta_{1}$ estuvo altamente correlacionada con el número de plaquetas presente en el PC. La metodología descrita permite producir PG con potencial terapéutico en medicina regenerativa canina.
\end{abstract}

Palabras clave: gel de plaquetas, plasma rico en plaquetas, perro, medicina regenerativa, factores de crecimiento, sales de calcio.

\section{SUMMARY}

The objectives of this study were: 1 ) to measure the concentrations of transforming growth factor beta 1 (TGF- $\left.\beta_{1}\right)$ and platelet-derived growth factor type $\mathrm{AB}$ (PDGF-AB) in plasma and platelet gel (PG) activated with calcium salts (gluconate or chloride) in dogs, and 2) to determine correlations between cell results and growth factors (GF) concentrations. Blood samples were collected from fourteen Brazilian Fila dogs. EDTA was used to obtain whole blood and plasma while ACD-A solution was used to prepare platelet concentrates (PC). Calcium salts were added to PC to induce their gelification. Platelet and leukocyte count was performed before PC activation. The concentration of growth factors in PG supernatants and plasma was determined by ELISA. Statistically significant differences $(\mathrm{P}<0.01)$ between platelet and leukocyte count were observed when comparing whole blood and PC. No statistically significant differences were found between the concentrations of TGF- $\beta_{1}$ and PDGF-AB in PC and plasma according to the calcium salt used for the activation of PC. The TGF- $\beta_{1}$ concentration was highly correlated with the number of platelets concentrated in the PC. This methodology was useful for producing PG with therapeutic potential for canine regenerative medicine.

Key words: platelet gel, platelet rich-plasma, dog, regenerative medicine, growth factors, calcium salts.

\section{INTRODUCTION}

Under physiological conditions, platelets (after activated) release substantial amounts of growth factors (GF), such as transforming growth factor beta 1 (TGF- $\beta_{1}$ ), platelet-derived growth factor (PDGF) and, other proteins that modulate inflammation and wound repair (Sutter et al 2004, Argüelles et al 2006). Platelet concentrates (PC)

Accepted: 20.12.2012.

* Calle 65 No 26-10, Manizales, Caldas, Colombia; raul.silva@ucaldas.edu.co (also known as platelet-rich plasma - PRP) are an autologous source of GF and therefore have been widely used in human medicine for procedures such as alveolar-maxillary reconstruction (Thor et al 2007), plastic (Cho et al 2011) and orthopedic surgery (Hakimi et al 2010), sports medicine (treatment of tendon injuries in athletes) (Sánchez et al 2003), treatment of chronic skin ulcers (Greppi et al 2011) and corneal ulcers (Alio et al 2007), amongst others.

There is an increased use of PC in horses to treat chronic musculoskeletal diseases (Carmona et al 2007, Argüelles et al 2008, Waselau et al 2008). However, there are few reports on the clinical use of PC in dogs 
(Hauschild et al 2005) although this animal has been widely used as experimental model to evaluate the effect of PRP as an adjuvant biomaterial (single or combined with other substances) in maxillary bone regeneration (Dutra et al 2008) or appendicular bone regeneration models (You et al 2007), and in osseo-integration tests (Casati et al 2007).

Platelet concentrates has been clinically used in a liquid form for local injection in tendons, ligaments or joints (Carmona et al 2011). However, clinicians in some circumstances induce the activation of the PC by adding an activating substance, such as thrombin or a calcium salt (Mazzucco et al 2008). This procedure induces platelet activation with externalization of alpha granules and release of growth factors, polymerization of fibrin and subsequent formation of a platelet gel (PG) (Dohan Ehrenfest et al 2006). PG are used as biomaterials in orthopedic, ocular, nervous or skin surgical procedures (Anitua et al 2007).

Recently, we described a simple manual tube method procedure for producing PC from canine blood intended for regenerative medicine porpoises in this species (Silva et al 2011). In this manuscript we present an analysis of the release of two GF (TGF- $\beta_{1}$ and PDGF-AB) stored in canine platelets from PG activated with two calcium salts, gluconate and chloride. This is a novel study, since there is little information about the release of these growth factors from canine PG.

The objectives in this study were 1) to measure and to compare the concentration of growth factors TGF- $\beta_{1}$ and PDGF-AB in plasma and PG supernatants obtained from canine PC that were activated either with calcium gluconate $10 \%$ or calcium chloride $10 \%$ and 2) to determine correlations between cell results and concentrations of the growth factors studied. The hypothesis of this study was that the release of TGF- $\beta_{1}$ and PDGF-AB from canine $\mathrm{PG}$ is the same independent of the calcium salt used for platelet activation.

\section{MATERIAL AND METHODS}

\section{ANIMALS}

Fourteen Brazilian Fila dogs from local breeders were used, seven males and seven females with a median age of 36 months (range 18 to 108 months), clinically healthy at time of blood collection and serologically negative for leishmaniasis and ehrlichiosis. Dogs with platelet counts less than $175 \times 10^{3} \mathrm{PLT} / \mu \mathrm{L}$ were not included (Jain 1993). This study was approved by the local ethics committee, protocol number 125/2009.

\section{PREPARATION OF PLATELET CONCENTRATES}

We used the tube method described by Silva et al (2011) for producing canine PC. Briefly, blood collection was performed by saphenous vein puncture with a butterfly catheter $21 \mathrm{G}$ (Shandong Weigao Group, Wheihai, China). Two blood samples of each animal were placed in an $8.5 \mathrm{~mL}$ tube with $1.5 \mathrm{~mL}$ ACD solution A (ACD-A) (trisodium citrate $22 \mathrm{~g} / \mathrm{L}$, citric acid $8 \mathrm{~g} / \mathrm{L}$ and dextrose $24.5 \mathrm{~g} / \mathrm{L}$ ) (Becton Dickinson and Company, New Jersey, USA). The samples were left on ice for 30 minutes before starting the experiments. A further blood sample was placed in a $4.5 \mathrm{~mL}$ tube with $\mathrm{k}_{3}$ EDTA (Ethylenediaminetetraacetic acid) (Shandong Weigao Group, Wheihai, China) for complete blood count (CBC). To obtain the $\mathrm{PC}$, the ACD-A blood tube was centrifuged at $191 \mathrm{~g}$ for 6 minutes at $4{ }^{\circ} \mathrm{C}$ (SIGMA 3K30, Osterade, Germany). Next, a micropipette of a fixed volume of $1000 \mu \mathrm{L}$ was used to collect (approximately), the first $100 \mu \mathrm{L}$ of the red portion and the first $900 \mu \mathrm{L}$ of plasma, below and above the interface blood-plasma, respectively.

\section{CELL EVALUATION}

Samples were analyzed using automated counting device by volumetric impedance (Abacus Junior Vet, Budapest, Hungary). Each sample was analyzed by triplicate. The hematological parameters tested were PCV, platelet count $(\mathrm{PLT} / \mu \mathrm{L})$, leukocytes $(\mathrm{WBC} / \mu \mathrm{L})$, relative (\% cells) and absolute (cells $/ \mu \mathrm{L})$ values of LYM, MID, GRA and mean platelet volume (MPV fL) (Silva et al 2011).

\section{ACTIVATION OF PLATELET CONCENTRATES AND FORMATION OF THE PLATELET GELS}

One $\mathrm{mL}$ of $\mathrm{PC}$ from each animal was activated with $0.1 \mathrm{~mL}$ of calcium gluconate $10 \%$ or $0.1 \mathrm{~mL}$ of calcium chloride $10 \%$. After activated, the samples were kept in incubation with calcium salts at room temperature (22$26^{\circ} \mathrm{C}$ ) for two hours (Argüelles et al 2006). Platelet gels were released from the tube walls and centrifuged at 1500 $\mathrm{g}$ for 10 minutes. Plasma was obtained from blood with EDTA by the centrifugation protocol described above. The PG supernatants and plasma samples were aliquoted and frozen at $-80{ }^{\circ} \mathrm{C}$ for later determination of TGF- $\beta_{1}$ and PDGF-AB.

\section{DETERMINATION OF THE CONCENTRATION OF TRANSFORMING GROWTH FACTOR BETA 1 AND PLATELET-DERIVED GROWTH FACTOR TYPE AB}

The concentration of both GF in plasma and PG supernatans were determined by ELISA sandwich with specific antibodies against canine TGF- $\beta_{1}$ (Mouse/Rat/ Porcine/Canine TGF- $\beta_{1}$, MB100B, R\&D Systems, Minneapolis, USA) and human PDGF-AB (Human PDGFAB, DHD00B, R\&D Systems, Minneapolis, USA), with a mean detection sensitivity of 4.6 and $1.7 \mathrm{pg} / \mathrm{mL}$, respectively. ELISA was performed by duplicate for each sample according to the manufacturer. Reading (Bio- 
chrom, Anthos 2010, Cambridge, UK) was performed at $450 \mathrm{~nm}$ and $540 \mathrm{~nm}$ for TGF- $\beta_{1}$ and PDGF-AB, respectively. GF concentration only were measured in samples from 12 dogs.

\section{STATISTICAL ANALYSIS}

Data was evaluated for normality by using the Shapiro-Wilk test. Cell results and TGF- $\beta_{1}$ concentrations were presented as mean and mean standard error. The concentrations of PDGF-AB were presented as median and interquartile range. Cell data from whole blood and PC were compared by using the student's test $(t)$ for paired samples. A one-way ANOVA was performed to compare TGF- $\beta_{1}$ concentration in plasma and PG supernatants. The PDGF-AB concentrations were analyzed by a Friedman test. PDGF-AB only was detected in the $45 \%$ of the samples, (left-censored data), and for the statistical analysis these values were matched to the ELISA's detection threshold test $(1.7 \mathrm{pg} / \mathrm{mL})$. Both GF were tested for correlation with cell counts by using Pearson and Spearman tests. The accepted statis- tical difference was $\mathrm{P} \leq 0.05$ for all tests. The statistical program SPSS 16.0 (SPSS Inc, Chicago, IL, USA) was used for this analysis.

\section{RESULTS}

\section{CELL EVALUATION}

Cell counts in whole blood and PC presented statistically significant differences $(\mathrm{P}<0.01)$ with respect to the values of PLT, WBC, relative and absolutes values of GRA, absolutes of MID, relatives of PCV and LYM. However, there were no statistically significant differences in absolute values of LYM and relatives values of MID (table 1).

\section{TRANSFORMING GROWTH FACTOR BETA 1 (TGF- $\left.\beta_{1}\right)$}

There were no statistically significant differences between concentrations of plasma and the PG supernatants activated with calcium gluconate or calcium chloride (table 2).

Table 1. Overall results of the cellular variables (data presented as mean (standard error)).

Resultados generales de las variables celulares (datos presentados como media (error estándar)).

\begin{tabular}{|c|c|c|c|}
\hline Variable & Whole Blood & Platelet Concentrate & $P$ value \\
\hline PLT (fragments $\times 10^{3} / \mu \mathrm{L}$ ) & $366.65(30.25)$ & $570.82(42.42)$ & $<0.001$ \\
\hline PCV \% & $44.30(1.39)$ & $4.33(0.73)$ & $<0.001$ \\
\hline WBC (cells x $10^{3} / \mu \mathrm{L}$ ) & $14.11(1.44)$ & $7.05(0.44)$ & $<0.001$ \\
\hline LYM (cells x $\left.10^{3} / \mu \mathrm{L}\right)$ & $3.63(0.95)$ & $3.40(0.34)$ & NS \\
\hline LYM\% & $22.03(2.96)$ & $50.77(4.74)$ & $<0.001$ \\
\hline MID (cells x $\left.10^{3} / \mu \mathrm{L}\right)$ & $0.63(0.14)$ & $0.23(0.03)$ & $<0.001$ \\
\hline MID \% & $4.07(0.39)$ & $3.26(0.39)$ & NS \\
\hline GRA (cells $\left.x 10^{3} / \mu \mathrm{L}\right)$ & $9.85(0.66) \mathrm{a}$ & $3.41(0.40)$ & $<0.001$ \\
\hline GRA\% & $73.92(3.03) \mathrm{a}$ & $44.32(4.20)$ & $<0.001$ \\
\hline
\end{tabular}

Statistically significant differences by t test. NS = Non significant.

Diferencias estadísticamente significativas mediante la prueba t. NS = no significativo.

Table 2. TGF- $\beta_{1}$ concentration in plasma and supernatants of platelet concentrates (PC) activated with calcium gluconate or calcium chloride (data presented as mean (standard error)).

Concentración de TGF- $\beta_{1}$ en plasma y en sobrenadante de concentrados autólogos de plaquetas (PC) activados con gluconato o cloruro de calcio (datos presentados como media (error estándar)).

\begin{tabular}{ccc}
\hline Blood component & TGF- $\beta_{1}$ ng/mL & P value \\
\hline Plasma $(n: 12)^{*}$ & $22.08(3.79)$ & NS \\
Platelet concentrate activated with calcium Gluconate** & $19.55(2.69)$ & NS \\
Platelet concentrate activated with calcium Chloride** & $19.98(1.58)$ & NS \\
\hline
\end{tabular}

* EDTA was use as anticoagulant. ** ACD-A was used as anticoagulant. NS = Non significant.

* EDTA fue usado como anticoagulante. ** ACD-A fue usado como anticoagulante. NS = no significativo. 


\section{PLATELET-DERIVED GROWTH FACTOR AB (PDGF-AB)}

The PDGF-AB concentrations were not detected in some samples. This GF was detected in $66 \%$ in the plasma samples obtained with EDTA. PDGF-AB was detected in $41.6 \%$ of the PG supernatants, however this GF was not detected always in the same samples (table 3). There were no statistically significant differences between plasma concentrations and the concentrations obtained for this GF in the PG supernatants, either activated with calcium gluconate or calcium chloride.

\section{CORRELATIONS}

No correlation between plasma concentrations of both growth factors and the number of platelets in whole blood counts with EDTA was found. However, positive Pearson's correlations ( $\rho$ ) were found between PLT/ $\mu \mathrm{L}$ count in PC and TGF- $\beta_{1}$ concentrations in the PG supernatans activated either with calcium gluconate $(\rho=0.746$ $\mathrm{P}=0.05)$ or calcium chloride $(\rho=0.836 \mathrm{P}=0.01)$. There was no correlation between the PDGF-AB concentrations and cell counts.

\section{DISCUSSION}

There are some controversies about the classification of PC intended for regenerative medicine purposes in humans. There is some consensus for classifying PC in function of the cellular content and the quality of the fibrin mesh formed after PC activation. In general, PC with platelet count 1.3 to 3 fold and WBC count similar or slightly inferior to the whole blood values are consi- dered as pure-platelet rich plasma (P-PRP) (Dohan Ehrenfest et al 2011). On the other hand, when PC present a platelet count 4 fold or more and WBC count 2 fold or more compared to the basal count of these cells in whole blood, these PC are considered as leukocyte-platelet rich plasma (L-PRP) (Dohan Ehrenfest et al 2011). When both PRP are activated with calcium salts or thrombin a PG is formed. The PG obtained from P-PRP is termed pure-platelet rich gel (P-PRG) and the gel obtained from L-PRP is known as L-PRG (Dohan Ehrenfest et al 2011). The PC obtained with the method evaluated in this study is thus considered as P-PRP and the gel obtained after activation should be considered as P-PRG. This is the first study describing the initial release of TGF- $\beta_{1}$ and PDGF$\mathrm{AB}$ from canine P-PRG.

An effective method for concentrating platelets should firstly focus on obtaining live and non-activated platelets instead of concentrating a large number of them (Marx 2004). The technical procedures used in this study for preventing platelet activation (and consequently producing release of platelet GF) (Ferrer et al 2001, Egidi et al 2010) during PC preparation, were: 1) storage of blood samples in ice during 30 minutes and 2) centrifugation at low temperature $\left(4^{\circ} \mathrm{C}\right)$. This methodology has been used to determine plasma TGF- $\beta_{1}$ concentration without interference of platelet activation (Heinemeier et al 2003). However, it is very important to consider that when cold storage or centrifugation time is prolonged platelets are activated and could develop cold storage-related lesions (Ayukawa et al 2009, Shrivastava 2009).

The MVP values in our study did not differ between whole blood and PC, and were within the normal range described for dogs (Boudreaux and Ebbe 1998). EDTA

Table 3. Median (interquartile range) of the concentration ( $\mathrm{pg} / \mathrm{mL}$ ) of platelet derived growth factor AB in plasma and platelet concentrate (PC) supernatants activated with either calcium gluconate or calcium chloride.

Mediana (rango intercuartil) de la concentración $(\mathrm{pg} / \mathrm{mL}$ ) de factor de crecimiento derivado de plaquetas $\mathrm{AB}$ en plasma y sobrenadante de concentrado autólogo de plaquetas (PC) activados con gluconato de calcio o cloruro de calcio.

\begin{tabular}{cccc}
\hline Dog \# & Plasma & PC activated with calcium Gluconate & PC activated with calcium chloride \\
\hline 1 & 140.46 & 222.3 & 167.64 \\
2 & 305.19 & 167.64 & 59.26 \\
3 & 86.31 & - & 113.36 \\
4 & 140.46 & 194.92 & - \\
5 & 167.64 & - & 86.31 \\
6 & 222.3 & - & 194.92 \\
7 & 113.36 & 59.26 & - \\
8 & - & - & - \\
9 & - & - & - \\
10 & - & 249.8 & - \\
11 & 59.26 & - & $(214.62)$ \\
12 & - & 1.70 & $1.70(120.88)$ \\
\hline
\end{tabular}


was used in this research because this substance is considered the anticoagulant of choice for counting blood cells (Wayne 2003), as well as for preserving cell morphology and avoiding the effect of to dilute the sample (Meinkoth and Allison 2007). However, we believe that the anticoagulant (EDTA) used for both basal hemogram and for collecting plasma, affected the TGF- $\beta_{1}$ and PDGF-AB concentration, since this anticoagulant produce platelet damage and consequently release of platelet related GF. In this sense, the plasma concentration of the GF evaluated in this study presented an artifactual increase of the GF related with functional and structural damage of the platelets possibly without inducing platelet activation. This fact limited our study since EDTA is not an ideal anticoagulant for measuring platelet activation (Macey et al 2002). This technical condition prevents the comparison between the plasma and PG supernatants of these GF and further studies are necessary to know the real plasma concentration of these proteins by using ACD-A as anticoagulant.

Vieweg et al (1999) reported the serum TGF- $\beta_{1}$ concentration for two dogs (16.5 and $19.9 \mathrm{ng} / \mathrm{mL})$ using a human ELISA kit. Although they were not representative, the average values of plasma and supernatants obtained from PG were closer to the data obtained in our study. Moreover, another study (Neumann et al 2008) described plasma TGF- $\beta_{1}$ concentrations between 0.193 y $0.598 \mathrm{ng} / \mathrm{mL}$ in 29 canine blood samples collected with EDTA that were obtained by double centrifugation at $1000 \mathrm{~g}$ x 15 minutes followed by $10000 \mathrm{~g} \mathrm{x} 10$ minutes at an temperature of $4{ }^{\circ} \mathrm{C}$. These values were substantially lower than those obtained in our study in plasma by using a single centrifugation episode and the same anticoagulant and temperature during centrifugation.

In this study, no difference was found between the TGF- $\beta_{1}$ and PDGF-AB concentrations in P-PRG supernatants activated with calcium gluconate or with calcium chloride at the same concentration and dose, which may indicate that the canine PC could be activated by any of these substances. Stief et al (2011) obtained mean TGF- $\beta_{1}$ concentrations of $1.2399 \pm 0.5908 \mathrm{ng} / \mathrm{mL}$ in autologous conditioned plasma (ACP) obtained with ACD-A in 10 dogs. The concentrations were lower than the TGF- $\beta_{1}$ concentrations in the P-PRG supernatants of our study. The protocol used in this study allowed us to concentrate a higher average number of platelets $\left(570.82 \times 10^{3} / \mu \mathrm{L}\right)$ when compared to the reports of Stief et al (2011), who did not report a correlation between platelet count and TGF- $\beta_{1}$ concentration in the ACP supernatants. It is important to bear in mind that the ACP and our PC could be technically classified as P-PRP, but the cellular concentration of both substances dramatically influenced in their own profile of growth factors.

On the other hand, the differences found for the TGF- $\beta_{1}$ concentration measured in our study, when compared to other studies (Vercelli et al 2003, Neumann et al 2008, Stief et al 2011), could be due to the methodology used for collecting and processing the samples, and potentially due to the fact that in our study we used a canine-specific ELISA kit. This last situation was not considered in the aforementioned studies where humanspecific ELISA kits were used (Vercelli et al 2003, Neumann et al 2008, Stief et al 2011).

Using an ELISA kit for determination of human PDGF-AB, Vieweg et al (1999) reported a mean serum PDGF-AB concentration of $410.77 \pm 177.56 \mathrm{pg} / \mathrm{mL}$ in seven dogs. However, other study (Stief et al 2011) using the same kit was unable to detect the concentration of this GF in plasma samples of 10 dogs. In our study, which used an ELISA kit similar to that used in previously mentioned studies, no reading was obtained for all samples in both plasma and P-PRG supernatants. In general, PDGF-AB concentrations in this study were about half the concentrations reported for Vieweg et al (1999). These differences could be due to the methodology for collecting and processing the samples. The failure to obtain readings by using this ELISA kit could be caused by a low activity of the PDGF present in dog serum and plasma (Bowen-Pope et al 1989) and to low homology between human and dog PDFG-AB.

The methodology used in our study is useful for producing PG and consequently release growth factors that might be acceptable for clinical or experimental use as a regenerative therapy in dogs. The relevance of the method reported here is that platelets can be concentrated by using ACD-A as anticoagulant, at single and soft centrifugation during short time. Our hypothesis was confirmed, since the GF concentration in P-PRG supernatants was similar when both calcium salts were used (gluconate or chloride) for PC activation. However TGF- $\beta_{1}$ concentration was highly correlated with the number of platelets concentrated in the PC (P-PRP).

\section{ACKNOWLEDGEMENTS}

The authors would like to thank the Coordenação de Aperfeiçoamento de Pessoal de Nivel Superior (CAPES) and Fundação de Amparo à Pesquisa do Estado de Minas Gerais (FAPEMIG).

\section{REFERENCES}

Alio JL, M Abad, A Artola, JL Rodriguez-Prats, S Pastor, J Ruiz-Colecha. 2007. Use of autologous platelet-rich plasma in the treatment of dormant corneal ulcers. Ophthalmology 114, 1286-1293.

Anitua E, M Sánchez, G Orive, I Andia. 2007. The potential impact of the preparation rich in growth factors (PRGF) in different medical fields. Biomaterials 28, 4551-4560.

Argüelles D, JU Carmona, J Pastor, A Iborra, L Viñals, P Martínes, E Bach, M Prades. 2006. Evaluation of single and double centrifugation tube methods for concentrating equine platelets. Res Vet Sci 81, 237-245. 
Argüelles D, JU Carmona, F Climent, E Muñoz, M Prades. 2008. Autologous platelet concentrates as a treatment for musculoskeletal lesions in five horses. Vet Rec 162, 208-211.

Ayukawa O, K Nakamura, H Kariyazono, R Ikeda, J Arima, T Shinkawa, H Iwase, R Sakata, K Yamada. 2009. Enhanced platelet responsiveness due to chilling and its relation to CD40 ligand level and platelet-leukocyte aggregate formation. Blood Coagul Fibrin 20, 176-184.

Boudreaux MK, S Ebbe.1998. Comparison of platelet number, mean platelet volume and platelet mass in five mammalian species. Comp Haematol Int 8, 16-20.

Bowen-Pope DF, CE Hart, RA Seifert. 1989. Sera and conditioned media contain different isoforms of platelet-derived growth factor (PDGF), which bind to different classes of PDGF receptor. J Biol Chem 264, 2502-2508.

Carmona JU, D Argüelles, F Climent, M Prades. 2007. Autologous platelet concentrates as a treatment of horses with osteoarthritis: a preliminary pilot clinical study. J Equine Vet Sci 27,167-170.

Carmona JU, C López, CE Giraldo. 2011. Use of autologous platelet concentrates as regenerative therapy for chronic diseases of the equine musculoskeletal system. Arch Med Vet 43, 1-11.

Casati MZ, BC Vasconcelos-Gurgel, PF Gonçalves, SP Pimentel, G Rocha-Nogueira, JRFH Nociti, EA Sallum. 2007. Platelet-rich plasma does not improve bone regeneration around peri-implant bone defects - A pilot study in dogs. Int J Oral Maxillofac Surg 36, 132-136.

Cho JM, YH Lee, RM Baek, SW Lee. 2011. Effect of plateletrich plasma on ultraviolet b-induced skin wrinkles in nude mice. J Plast Reconstr Aesthet Surg 64, e31-e39.

Dohan Ehrenfest DM, J Choukroun, A Diss, SL Dohan, AJ Dohan, J Mouhyi, B Gogly. 2006. Platelet-rich fibrin (PRF): a second-generation platelet concentrate. Part II: plateletrelated biologic features. Oral Surg Oral Med Oral Pathol Oral Radiol Endod 101, e45-e50.

Dohan Ehrenfest DM, T Bielecki, A Mishra, P Borzini, F Inchingolo, G Sammartino, L Rasmusson, PA Everts. 2011. In search of a consensus terminology in the field of platelet concentrates for surgical use: platelet-rich plasma (PRP), platelet-rich fibrin (PRF), fibrin gel polymerization and leukocytes. Curr Pharm Biotechnol 13, 1131-1137.

Dutra CEA, MM Pereira, R Serakides, CMF Rezende. 2008. In vivo evaluation of bioactive glass foams associated with platelet-rich plasma in bone defects. J Tissue Eng Regen Med 2, 221-227.

Egidi MG, A D'Alessandro, G Mandarello, L Zolla. 2010. Troubleshooting in platelet storage temperature and new perspectives through proteomics. Blood Transfus 8, 73S$81 \mathrm{~S}$.

Ferrer F, J Rivera, ML Lozano, J Corral, W García. 2001. Effect of cold-storage on the accumulation of bioreactive substances in platelet concentrates treated with second messenger effectors. Haematologica 86, 530-536.

Greppi N, L Mazzucco, G Galetti, F Bona, E Petrillo, C Smacchia, E Raspollini, P Cossovich, R Caprioli, P Borzini, P Rebulla, M Marconi. 2011. Treatment of recalcitrant ulcers with allogeneic platelet gel from pooled platelets in aged hypomobile patients. Biologicals 39, 73-80.

Hakimi M, P Jungbluth, M Sager, M Betsch, M Herten, J Becker, J Windolf, M Wild. 2010. Combined use of platelet- rich plasma and autologous bone grafts in the treatment of long bone defects in mini-pigs. Injury 41, 717-723.

Hauschild G, HA Merten, A Bader, G Uhr, A Deivick, A MeyeLindenberg, M Fehr. 2005. Bioartificial bone grafting: Tarsal joint fusion in a dog using a bioartificial composite bone graft consisting of beta-tricalciumphosphate and platelet rich plasma- a case report. Vet Comp Orthop Traumatol 18, 52-54.

Heinemeier K, H Langberg, M Kjaer. 2003. Exercise-induced changes in circulating levels of transforming growth factor-beta-1 in humans: methodological considerations. Eur J Appl Physiol 90, 171-177.

Jain NC. 1993. Essentials of veterinary hematology. Lea \& Febiger, Philadelphia, USA, Pp 105-132.

Macey M, U Azam, D McCarthy, L Webb, ES Chapman, D Okrongly, D Zelmanovic, A Newland. 2002. Evaluation of the anticoagulants EDTA and citrate, theophylline, adenosine, and dipyridamole (CTAD) for assessing platelet activation on the ADVIA 120 Hematology System. Clin Chem 48, 891-899.

Marx RE. 2004. Platelet-rich plasma: evidence to support its usage. J Oral Maxillofac Surg 62, 489-496.

Mazzucco L, V Balbo, E Cattana, P Borzini. 2008. Platelet-rich plasma and platelet gel preparation using Plateltex. Vox Sang 94, 202-208.

Meinkoth JH, RW Allison. 2007. Sampling collection and handling: getting accurate results. Vet Clin Small Anim 37, 203-219.

Neumann S, FJ Kaup, B Beardi. 2008. Plasma concentration of transforming growth factor-beta1 and hepatic fibrosis in dogs. Can J Vet Res 72, 428-431.

Sánchez M, J Azofra, E Anitua, I Andía, S Padilla, J Santisteban, I Mujika. 2003. Plasma rich in growth factors to treat an articular cartilage avulsion: a case report. $\mathrm{Med} \mathrm{Sci}$ Sports Exerc 35, 1648-1652.

Shrivastava M. 2009. The platelet storage lesion. Transfus Apher Sci 41, 105-113.

Silva RF, CMF Rezende, FO Paes-Leme, JU Carmona. 2011. Evaluation of the tube method for concentrating canine platelets: cellular study. Arch Med Vet 43, 95-98.

Stief M, J Gottschalk, JC Ionita, A Einspanier, G Oechtering, P Böttcher. 2011. Concentration of platelets and growth factors in canine autologous conditioned plasma. Vet Comp Orthop Traumatol 24, 122-1225.

Sutter WW, AJ Kaneps, AL Bertone. 2004. Comparison of hematologic values and transforming growth factor- $\beta 1$ and insulin-like growth factor concentrations in platelets concentrates obtained by use of buffy coat and apheresis methods from equine blood. Am J Vet Res 65, 924-930.

Thor A, V Franke-Stenport, CB Johansson, L Rasmusson. 2007. Early bone formation in humans bone grafts treated with platelet-rich plasma: preliminary histomorphometric results. Int J Oral Maxillofac Surg 36, 1164-1171.

Vercelli A, G Bellone, O Abate, G Emanuelli, A Cagnasso. 2003. Expression of transforming growth factor-beta isoforms in the skin, kidney, pancreas and bladder in a German shepherd dog affected by renal cystadenocarcinoma and nodular dermatofibrosis. J Vet Med A Physiol Pathol Clin Med 50, 506-510.

Vieweg U, J Schramm, H Urbach. 1999. Platelet-derived growth factor (PDGF-AB) like immune reactivity in serum and in 
cerebral spinal fluid following experimental subarachnoid haemorrhage in dogs. Acta Neurochir 141, 861-855.

Waselau M, WW Sutter, RL Genovese, AL Bertone. 2008. Intralesional injection of platelet-rich plasma followed by controlled exercise for treatment of midbody suspensory ligament desmitis in Standardbred racehorses. J Am Vet Med Assoc 232, 1515-1520.

Wayne PA. 2003. Tubes and additives for venous blood speci- men collection; approved standard. $5^{\text {th }}$ ed. Document H1A5. National Committee for Clinical Laboratory Standards 33, Pennsylvania, USA.

You TM, BH Choi, J Li, JH Jung, HJ Lee, SH Lee, SM Jeong. 2007. The effect of platelet-rich plasma on bone healing around implants placed in bone defects treated With Biooss: a pilot study in the dog tibia. Oral Surg Oral Med Oral Pathol Oral Radiol Endod 103, 8-12. 
